\title{
Displaying Colonial Relations: from Government House in Fiji to the University of Cambridge Museum of Archaeology and Anthropology
}

\author{
Anita Herle*
}

\begin{abstract}
This paper focuses on the assemblage and display of Fijian collections at Government House during the first few years of British colonial rule and considers its re-presentation in the exhibition Chiefs \& Governors: Art and Power in Fiji (6 June 2013 - 19 April 21014) at the University of Cambridge Museum of Archaeology and Anthropology (MAA). It moves beyond reductionist accounts of colonial collecting and investigates the specificity and nuances of complex relationships between Fijian and British agents, between subjects and objects, both in the field and in the museum. A focus on the processes of collecting and display highlights multiple agencies within colonial networks and the fluid transactional nature of object histories. The Fijian objects that bedecked the walls of Government House from the mid 1870s were re-assembled in 1883 as the founding ethnographic collections of the University of Cambridge Museum of General and Local Archaeology (now MAA). Ethnographic museums have tended to efface the links between the material on display and their colonial pasts (Edwards and Mead 2013). In contrast, the creation of Chiefs \& Governors was used as an opportunity to attend to the materiality the objects and explore the multiple agencies within colonial relations and processes of collecting, displaying and governing (Bennett et al.2014; Cameron and McCarthy 2015). The second half of this paper analyzes the techniques and challenges involved in displaying colonial relations in a museum exhibition and considers the ongoing value of the collections for Fijian communities, cultural descendants, museum staff, researchers and broad public audiences today.
\end{abstract}

\section{Introduction}

You can't think how well it looks. Such beautiful and artistic patterns can be made with clubs, spears, bowls, arrows, axes, paddles, etc. We have an immense collection of these things now between us, increasing every day and others have lent theirs to be hung up. The room is large and high, so that there is great scope for it... Over each of the nine doors in the dining-room we have put up a very large kava bowl, from three to four feet across, with a club on each side (Gordon 1897: 292).

In October 1875, a few months after Sir Arthur Gordon took up the first Governorship of Fiji, Lady Gordon wrote to her sister Madeleine Shaw-Lefevre describing her delight in decorating the dining room at Government House.

The dramatic effect produced by the display is spectacularly shown in a photograph of the back wall of the dining room (Fig. 1). It is an iconic display of colonial power - a collection of trophies with the bilaterally symmetrical arrangement in keeping with Victorian sensibilities and reminiscent of a hunting lodge. The interest in forming comprehensive collections reflected an underlying imperialist desire to collect and classify the world, which was facilitated by farreaching colonial networks. The aetheticisation of the presentation played with morphology 
and suggests a much broader reordering of aspects of Fijian culture (Thomas 1989: 51). Yet, the context and meaning of the display is equivocal. The presence of the photographic still life prompts questions about the sociality beyond the frame. An exploration of the processes involved in collecting demonstrates multiple overlapping interests and complex interactions between the residents of Government House and powerful chiefs and their families. The materialization of these relations on the walls of the dining room reveals a tension between and a conflation of colonial and Fijian ideas of value and chiefly presentation (Herle and Carreau 2013: 104-105).

This article focuses on the assemblage and display of the collections at Government House and reflexively considers its re-presentation in the exhibition Chiefs \& Governors: Art and Power in Fiji (7 June 2013 - 19 April 2014) at the Museum of Archaeology and Anthropology (MAA), University of Cambridge. ${ }^{1}$ The 'mania for collecting curiosities' with which the residents were 'bitten' (Gordon 1897: 292) resulted in the most comprehensive nineteenth century collection of Fijian artefacts. Largely assembled in just over two years, the bulk of the collection was eventually transferred to the University of Cambridge in 1883 where it was mobilized to assist with the founding of the Museum of General and Local Antiquities, now MAA. Recent research and exhibition of this material, as part of an AHRC research project on Fijian Art, $^{2}$ attended to the materiality of these highly valued things and the particular circumstances surrounding their acquisition and circulation. The objects have prompted a myriad of discoveries about the past, providing insights into pre-colonial history, indigenous Fijian beliefs and practices, the nuances of colonial relations, and the early development of MAA (Herle and Carreau 2013). The collection also continues to provide opportunities to forge relationships between Fijian communities, cultural descendants, museum staff and broader public audiences.

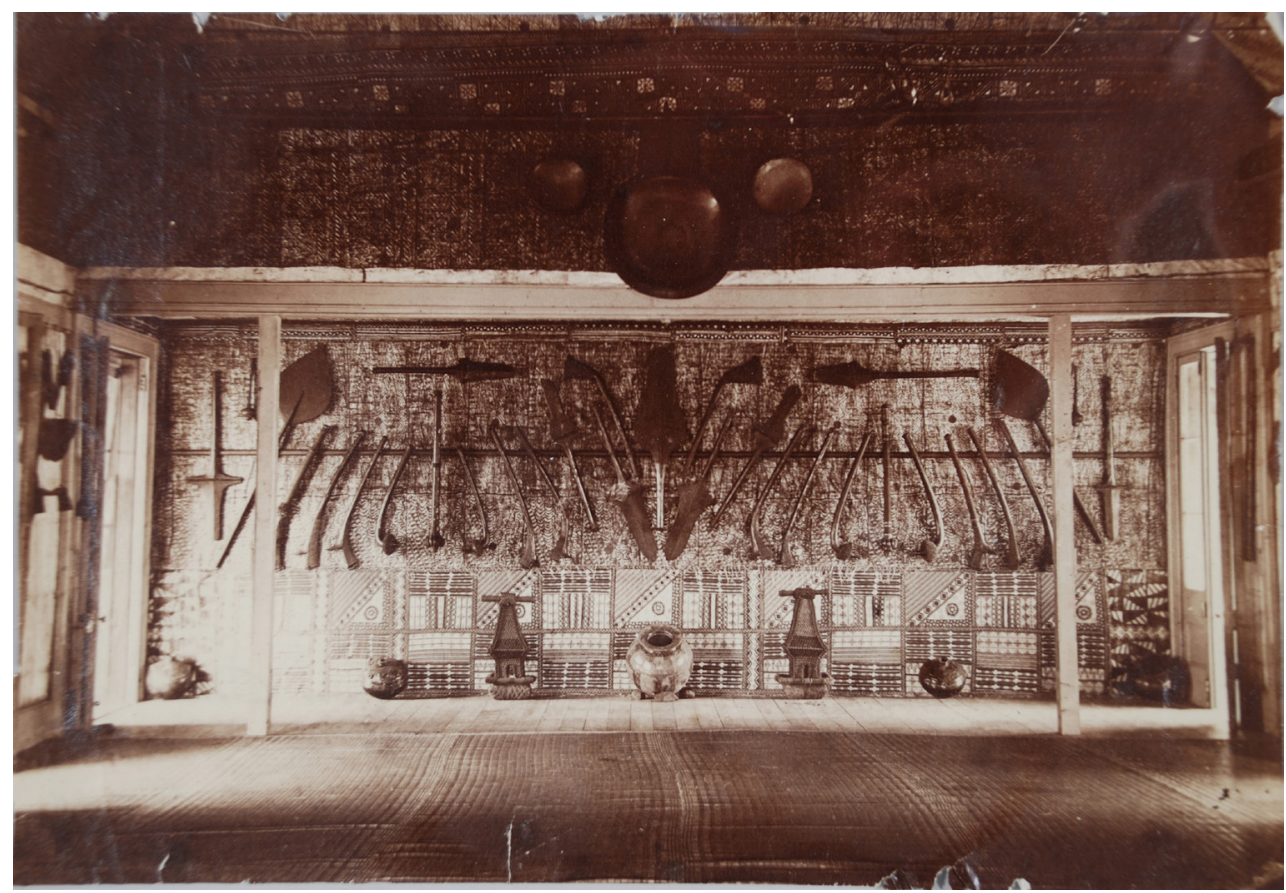

Figure 1. Back wall of the dining room at Government House, with weapons, paddles, yaqona bowls, pottery and portable spirit houses displayed in front of a large gatu vakaviti barkcloth. Photographed by F.H. Dufty, Nasova, Ovlau Island, c. 1875. Fiji. P.27782.VH 


\section{Assembling Fijian Collections at Government House}

The Fijian artefacts assembled at Government House were acquired by the official residents and guests of Sir Arthur Gordon's household shortly after Fiji's Cession to the British crown in October 1874. Prior to colonization, Fiji had been governed by a shaky alliance between white settlers and powerful chiefdoms, led by Cakobau, vunivalu (war-chief) of the island of Bau, who from 1871 was the self-proclaimed King of Fiji (Derrick 2001). Competition between matanitu (chiefdoms) was intense (Sahlins 2004), the tribes in the interior of Viti Levu fiercely opposed Cakobau's authority, the settler community was divided and Cakobau's foreign debts were rising. In an attempt to align itself with Queen Victoria, seen by politically savvy Fijians as the world's most powerful chief, the Cakobau government twice made a petition for Cession. The British were initially reluctant to assume power over Fiji, but concerns to protect the growing number of settlers, mitigate the exploitation of Fijians and control abuses in the Pacific labour trade resulted in a negotiated settlement. The Deed of Cession was signed in October 1874 by thirteen leading chiefs and the British representative Sir Hercules Robinson, Governor of New South Wales.

Sir Arthur Gordon, an experienced political and colonial administrator, then Governor of Mauritius, was appointed the first Governor of Fiji, arriving at his official residence at Nasova near the colonial capital of Levuka on 25 June 1875. His core team included two private secretaries - his nephew Arthur J.L. Gordon and George Le Hunte - as well as a small detachment of Royal Engineers. He was supported by established British and Australian settlers and the Armed Native Constabulary, led by Captain Louis Knollys. The residents of Government House soon included Baron Anatole von Hügel, a young British adventurer of Austrian descent. In September they were joined by Lady Gordon and her two children Rachel and George, accompanied by her travelling companion Constance Gordon Cumming and Alfred Maudslay, who joined Gordon's team as an additional Private Secretary.

The enthusiastic von Hügel has often been seen as the catalyst for collecting at Government House. Shortly after arriving in Fiji in May 1875, he started amassing material and made an arduous journey along the Rewa river to the interior of Viti Levu with a Fijian guide, Ro Saumaka, and a boy nicknamed Wally (Roth and Hooper 1990). Assisted by the experienced and sympathetic intermediary Walter Carew, a former planter recruited as District Commissioner, von Hügel focused on recording ornithological and ethnographic information and acquiring specimens. A.J. Gordon noted his passion on their first meeting and invited him to Government House. 'He was half-starved on native food, had spent all his money, and had even cut the buttons off his clothes to exchange for native ornaments' (Maudslay 1930: 87). While von Hügel's presence stimulated interest and competition at Nasova, by the time he took up residence at the end of July, Sir Arthur was already building up a collection and was keen to show him 'some pretty things which he had brought back from a cruise in the Government boat the Barracouta' (Roth and Hooper 1990: 100).

Over the following months new material was acquired almost daily. Not hampered by official government business, von Hügel was the most persistent, routinely 'grubbing' for material in nearby native villages and going into Levuka to check out what was on offer. An intense desire among, and friendly rivalry between, the residents at Nasova and some of the Levuka colonial elite developed around the acquisition of native artworks, which fuelled the supply. Von Hügel noted that some of the Levuka store-keepers '... made the sale of 'curios' a regular branch of trade. The prices of 'curios' rose tenfold in the short space of a few months' (Roth and Hooper 1990: 105). One of the middlemen was Francis Dufty, a skilled photographer and entrepreneur, who established his studio in Levuka in 1871, following the establishment of Cakobau's royal government. Dufty built up a collection of Fijian artefacts that he used as props in his photography, with many of the same objects re-appearing with different people in posed cartes-de-visit (Dudding 2013: 116). Von Hügel describes an occasion at Government House when Dufty captured the high-spirited attitude of the younger men in a series of posed photographs. 'Gordon, Le Hunte, Knollys and self were great in attitudinising over and beside the subjects - making most hideous grimaces, arming ourselves with knives etc. to represent “"The rival collectors"...' (Roth and Hooper 1990: 122). On hearing that Dufty had just acquired new material, they went immediately to his studio, 
... we had a very excited meeting, for the beauty of the lot of clubs, spears etc. was very intoxicating. We decided upon tossing, and after much ado decided things very well and amicably, each having a splendid lot of things... The Governor and Knollys came in just as we had our 'go' and both managed to find something good (Roth and Hooper 1990: 122).

The shared fascination with Fijian artefacts was given impetus by a keen, if vaguely defined, awareness of the scientific value of large collections. It was presumed that in order for a collection to be 'scientific' it needed to be based on European systems of classification. Von Hügel's interests were strongly influenced by his father Karl, a diplomat and noted botanist, who travelled widely in Asia and the Pacific collecting natural history and some ethnographic specimens. Karl established a botanical garden in Vienna and later donated plant samples to the British Museum. ${ }^{3}$ Initially von Hügel also focused on natural history, particularly the acquisition of bird specimens, but found others already engaged with ornithological work. The British Consulate Edgar Layard was collecting for the British Museum, Theodor Kleinschmidt for the Godeffroy Museum in Hamburg and E. P. Ramsay for the Australian Museum in Sydney (Roth and Hooper 1990: 13). While von Hügel continued to collect natural history throughout his extensive Fijian fieldtrips, ${ }^{4}$ he was keen to make his mark and his attention soon shifted to ethnography.

[N]o one had thought of making a local ethnological collection. A few scattered native weapons or implements might certainly be found in settlers' houses, but they were kept as 'curios', often for the sake of some sensational history which the owner could attach to them (Roth and Hooper 1990: 13).

Von Hügel differentiated between scientific collecting and the acquisition of the odd 'curio'. His collecting practice sought out the range and many variants of object types, with well-executed or unusual examples attracting particular attention. His careful method of labelling birds, with their Latin species, gender, date and place, was adapted for his ethnographic collections, his tiny hand-written labels and detailed notebooks and sketches providing a wealth of information for subsequent researchers (Carreau 2013: 91-92).

Von Hügel acknowledged Sir Arthur's keen appreciation 'of the scientific value of ethnological collections... Soon every room in Nasova had something of the Museum look about it' (Roth and Hooper 1990: 105). Their shared interests were likely influenced by current evolutionary thinking - they discussed Darwin over dinner at Nasova (Roth and Hooper 1990, 137). In addition to artefacts, von Hügel also built up an extensive collection of photographs, many of them stock images from Dufty's studio, which reflect an ethnological interest in social and racial variations.

Sir Arthur had sustained interests in anthropology, having become a Fellow of the Anthropological Institute in London in 1873, one of the very few colonial officers to do so at that time (von Hügel did not join until 1879, several years after he left Fiji). ${ }^{5}$ He planned to assemble a well-documented collection for the British Museum and within two months of his arrival in Fiji he wrote to Augustus Franks, Keeper of Medieval Antiquities and Ethnography at the British Museum, including rough sketches of clubs with their Fijian names:

My dear Franks, I send you a few photographs of good clubs? and of very curious and pretty pottery. Some of these are Von Hügels, but some are mine. Do you want any? You are welcome to my lot. Next mail I will send you photos of spears to select. ... I can give you the names of many of your clubs and shall soon be able to give you all... (Gordon to Franks 21 August 1875). ${ }^{6}$

Multiple and overlapping agendas gave impetus to this competitive fervour for collecting. Unlike many of the stereotypes associated with colonial collecting, objects were not extracted from a singular local context, and the terms on which they were acquired did not simply reflect colonial agendas. The different interests and processes involved were complex and variable with many encounters highlighting indigenous agency and local ingenuity. The availability of large numbers of Fijian artefacts partially reflected the poverty of many villagers suffering from the devastating measles epidemic that swept Fiji shortly before Gordon's arrival. Some items 
highly desired by collectors were pre-Christian relics and castoffs. Many of the objects sold or exchanged, such as carved yaqona bowls and masi (barkcloth) were, and still are, actively produced for local use. It is likely that collecting stimulated local production of these and other items. The large number of flesh or 'cannibal' forks in circulation included many examples that were produced to satisfy the European fascination with 'savage' practices that had been gradually subdued following the arrival of Western Methodist missionaries and their Tongan native teachers during the mid-1830s. ${ }^{7}$

Many Fijians were keen to trade for European goods, typically lengths of calico, metal items such as knives and fishhooks, and tobacco. Bypassing the Levuka shopkeepers, Fijians routinely turned up at Government House with items for sale. The agency of Fijians in different collecting encounters is most clearly demonstrated by von Hügel's unusual experience at the village of Nakorovatu [now Korowatu], a week into his journey up the Rewa River, which resulted in the acquisition of a large number artefacts, from everyday items to a magnificent whale ivory breastplate (MAA Z 2749; Carreau 2013: 91-92).

Immediately after food, trading began, as the people had had timely warning of my needs, and the whole evening through, clubs, spears, bows and arrows, dishes, dresses and ornaments kept pouring in. I had settled myself on a mat near one of the narrow doorways of the house... Through the opening would be thrust a club or a spear held by a black arm, which vanished as soon as the club or spear was taken from it. I would then examine the article and Carew would ask the price, which I handed to one of my boys to put on the doorstep... (Roth and Hooper 1990: 31).

This encounter is striking, not only because of the apparent keenness of numerous individual villagers to trade and the anonymity of the participants, but also because von Hügel purchased everything offered, and at a price that was locally determined - even items he later described as 'trash'. Divorced from the formalized cultural protocols typically involved in exchange, local Fijians, including women and people of low rank, appear to have determined what was to be collected (Thomas 2011: 301). Yet their eagerness to trade also can also be understood as an act of deference. Von Hügel, travelling with Carew, would have been seen as a kind of matanivanua (chief's spokesman) for the Governor. This large acquisition steered von Hügel in the direction of comprehensive collecting, including many items such as liku (women's skirts), which he only later came to appreciate (Jacobs 2013: 71)

Highly valued things have long been crucial in mediating and extending social relationships as part of complex networks of exchange and alliance that extended throughout Polynesia. Tabua, presentation sperm whale's teeth attached to a fibrous cord, continue to be the most valuable of all Fijian objects (Hooper 2013a: 21-22, 2013b). The proliferation and range of presentation items, including exquisite ornaments made from whale ivory, embodied the great mana of Fijian chiefs. Not surprisingly, the most valuable and rare items in the Government House collections were gifts to the Governor and Lady Gordon, presented in formal circumstances and intended to demonstrate and consolidate political and personal relationships (Fig. 2). These treasures were not visible on the dining room walls, but they were included in Constance Gordon Cumming's numerous sketches and watercolours depicting the Government House collections. ${ }^{8}$

Some of the gifts have distinctive biographies that continue to enhance their value. Gordon acquired a pearl shell and whale ivory breastplate (civavonovono), previously owned by Cakobau's father, Tanoa Visawaqa (MAAZ2730; Clunie 1983). ${ }^{9}$ While the exact circumstances of its acquisition are unrecorded, it is likely that it passed from Tanoa through Cakobau to Gordon. An exquisitely carved ivory hook, originating from Tonga and likely representing one of the small number of conjoined-twin goddesses worshipped in Tonga and Samoa, was transferred to Fiji in the first half of the nineteenth century and worshipped as an ancestor god named Nalilavatu, in a spirit house near Nadi. Following the arrival of Christianity, Nalilavatu was hidden and eventually acquired by Ratu Tevita Madigibuli of the Armed Native Constabulary, who presented the highly prized figure to Gordon (MAA 1955: 247; Clunie 2013: 55, Larsson 1960: 25-28). Gordon also received gifts from Cakobau's rival, the formidable Tongan Chief Ma'afu who gained control over much of the Lau islands from the mid-nineteenth century. 
Ma'afu's speech accompanying his presentation of a trolling bonito fishhook (bayaloyalo; MAA Z 3322) both demonstrated his alliance with the colonial regime and asserted his own power. 'You have got the land. I bring you the water, as land without water is useless. Here it is with all the fish and living creatures in it' (Roth and Hooper 1990: 120).

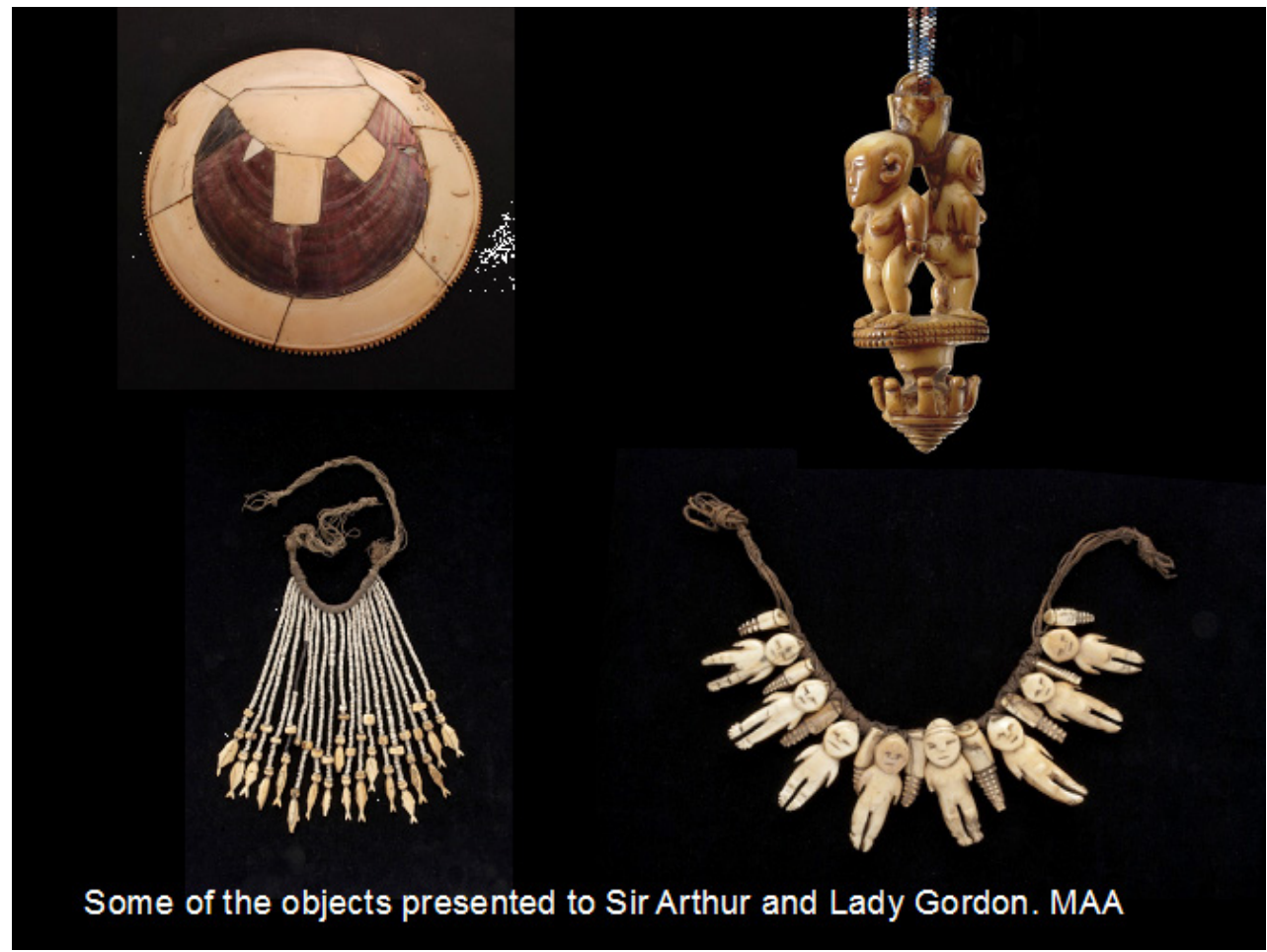

Figure 2. Some of the highly valued objects in the Gordons' collection. Top (I-r): Breastplate Civavonovono, composed of whale ivory and pearl shell, previously belonging to Cakobau's father Tanoa Visawaqa. Dia. $28 \mathrm{~cm}$. Z 2730. Whale ivory double-figure hook strung with glass beads on a fibre cord. H. $12.2 \mathrm{~cm} .1955 .247$. Bottom (I-r): Necklace with whale ivory pendants, and shells on coconut fibre cord. L. $61 \mathrm{~cm}$. Z 2270. Human-shaped figures and pendants of whale ivory strung on plaited coir cords. L. $52 \mathrm{~cm}$. Z 2752.

As Queen Victoria's representative, Gordon was treated as a chief and described himself as such. The Gordons were quick to incorporate local forms of chiefly sociality and protocols involving the exchange of valued objects, and kept a ready supply of tabua for this purpose. Gordon purchased whales' teeth from Dufty to decorate the staves that he presented to the Chiefs attending his formal installation as Governor (Roth and Hooper 1990: 124; Gordon 1897: 209). Lady Gordon offered a whale's tooth to Cakobau when he presented her with one of the last great drua (double-hulled canoes) as part of a strategic performance that enabled him to gift the boat to Lady Gordon, while receiving it back in his care 'to make use of it and sail for her' (Gordon 1901: 629-30).

The dining room of Government House was a key space for social engagement, combining domestic hospitality with careful political negotiations between Fijian and British elites. The Gordons regularly entertained Cakobau and other leading chiefs and their families. These occasions routinely included the ceremonial drinking of yaqona within a specially matted room designed for this purpose. The Fijianization of sociability at Government House was embodied 
in its hybrid architecture and decoration. Originally built for the Cakobau government, the building combined a European wooden framework and glazed doors and windows with Fijian reed-work and thatching. Within this physical and social context the prominent display of the Government House collections was in keeping with chiefly notions of presentation and value, albeit without the spiritual connotations associated with the pre-Christian practice of chiefs and leading warriors displaying weapons and other prized objects within spirit houses (Mills 2013: 53)..$^{10}$ The arrangement demonstrated Gordon's mana and established Government House as a material locus of concentrated power. Chief's homes also reflected their encounters and alliances with Europeans. Von Hügel describes Cakobau's 'magnificent large Fijian house... [containing] sundry chests of drawers with no end of crockery, lamps, etc. and various pictures, amongst others one of the King of Hanover presented by himself' (Roth and Hooper 1990: 109). The conscious adaptation of Fijian practices and aesthetics at Government House was highlighted by Gordon Cumming in a letter to her sister sent on 28 March 1876:

The dining-room is now beautifully decorated with trophies of spears and clubs, and great bowls, and native cloth. The house is all so thoroughly in keeping with the country; so infinitely preferable to any attempt at making a Europeanised "Government House," and so much more suitable to Sir Arthur's rôle of premier chief of Fiji (Gordon Cumming 1883: 149).

\section{The Dispersal of the Government House Collection}

The objects that bedecked Government House were gradually dispersed. The dynamic of the household shifted in the latter half of 1877, with von Hügel and Gordon Cumming returning separately to England and Maudslay dispatched to Samoa. Sir Arthur continued to acquire material until he left Fiji in 1880 to take up the position of Governor of New Zealand. His paternalistic commitment to the well-being of native Fijians and his bitter disappointment at plans to replace him in Fiji are evidenced in his letters to his wife and political superiors. ${ }^{11}$

Gordon and Maudslay were both Cambridge alumni and they offered their Fijian collections to the University of Cambridge in 1883, alongside the promise of extensive material from von Hügel. They were no doubt aware of the ongoing attempts by the Cambridge Antiquarian Society (CAS) to donate its growing collection to the University, subject to an agreement that a museum be established to house the material. The additional offer of a large and prestigious collection from the South Seas bolstered the CAS's longstanding campaign, and in 1884 the Cambridge Museum of General and Local Archaeology (now MAA) was established. Von Hügel was appointed the first Curator, a position he held for nearly 40 years (Ebin and Swallow 1984, Elliott and Thomas 2011).

While most of MAA's founding ethnographic material was assembled at Nasova, the idea of a unified Government House collection is a misapprehension. Instead there are numerous overlapping and porous collections, in which pieces were added and removed over many years. Following his correspondence with Franks, Gordon presented approximately one hundred objects to the British Museum in 1878, including a large number of pottery vessels and adzes. MAA's founding collection from Fiji included well over a thousand objects, but the vagaries of early museum documentation, in which objects were not individually accessioned but grouped under donor names, combined with the practice of re-numbering objects, has made it impossible to be specific. Von Hügel's material was initially a deposit and only later formally accessioned into the Museum's permanent collections. He used 'duplicates' to instigate exchanges with other collectors and museums, ${ }^{12}$ and he actively acquired new pieces from dealers and auction houses. Following the deaths of Gordon and Maudslay, in 1912 and 1931 respectively, further material from their collections was donated by their families. Three objects particularly prized by Gordon and his family were finally donated to MAA in 1955. It is revealing that these favoured personal objects have specific biographical associations, highlighting the capacity of objects to embody social relations and trigger memories. They include a 'cannibal fork' given to Gordon by von Hügel (MAA 1955.246), a beautifully patinated yaqona cup (MAA 1955.248) that had belonged to Cakobau, and the outstanding twinned ivory figure discussed above (MAA 1955.247). 
The presence of extensive Fijian material at MAA, the 'magnetic' quality of comprehensive displays which demand ever more objects to complete them (Gosden and Larkin 2007), and the interests of later Fijian scholars has propelled the growth of the collections. ${ }^{13}$ The systematic and painstaking research of the Fijian material at MAA, led by Lucie Carreau as part of the Fijian Art Project, clarified many documentation anomalies and connected information on labels and in archives with specific objects. Yet the acquisition dates for some of the objects remain uncertain. At the time of writing there were 2,946 catalogue entries for MAA's Fijian object collections, with 1,016 attributed to von Hügel, 508 to Gordon and 274 to Maudslay.

\section{Displaying Colonial Relations in Cambridge - Chiefs \& Governors: Art and Power in Fiji}

The Fijian Art Project provided the opportunity for a major exhibition at MAA which drew almost exclusively on the Cambridge collections and presented recent research. We were mindful that, despite a burgeoning field of post-colonial studies within academia, and powerful critiques of colonialism from Pacific Islander historians and within the literary, performing and visual arts, there have been relatively few museum exhibitions that explicitly explore the thorny colonial histories associated with many ethnographic collections. Concurrent European research highlighted the tendency of museum displays to erase the links between their collections and the colonial past (Edwards and Mead 2013, Edwards 2016). ${ }^{14}$ The reluctance of museums to engage with difficult histories is not only due to their complexity but also because of the danger of unintentionally reinforcing stereotypes and/or producing a backlash. The well-publicized protests prompted by the controversial 1989 exhibition 'Into the Heart of Africa' at the Royal Ontario Museum in Toronto had far-reaching effects (Butler 1999). ${ }^{15}$ During the period in which the Fiji exhibition was being prepared at MAA, the Tropenmuseum in Amsterdam, which featured a permanent exhibition on Dutch colonialism, was criticized for promoting self-hatred within Dutch society and threatened with the possible withdrawal of state funding (Modest 2014: 21-22).

The machinery and impact of colonialism varies greatly between and within in different contexts. Given the provenance of MAA's founding Fijian collections, it was decided to develop an underlying exhibition theme that would explore the complexity and specificity of the colonial relations within which the objects were deeply entangled. The exhibition title Chiefs \& Governors: Art and Power in Fiji was intended to evoke the political dynamic, as well as emphasize the agency of the extraordinary objects on display. While the exhibition focused on the 1870s and 1880 s, the period when most of the material was collected and transferred to Cambridge, the displays were situated within much broader historical and cultural contexts. Supplementing the founding collections with more recent acquisitions,${ }^{16}$ the juxtapositions of objects and texts facilitated multiple interpretative pathways through the displays.

The underlying narrative unfolded chronologically, from the eighteenth century movements of Islanders within Polynesia, through the impact of European traders and missionaries, settlement and colonization, and the foundation of MAA, and the importance of the collections today. The exhibition began with a model of a nineteenth century drua, a large double-hulled canoe. Drawing on the iconic concept of 'Our Sea of Islands', coined by the Tongan scholar Epeli Hau'ofa to reconceptualize the Pacific as a region where the islands are connected by the sea (Hau'ofa 1993), the audience was positioned in a dynamic Pacific region, gradually infiltrated by European explorers, traders, missionaries and settlers. The presentation aimed to highlight the fluid transactional nature of object histories and challenge the commonly held assumption that museum artefacts are necessarily linked to a singular point of origin. Objects on display included a Tongan ivory figurine collected in Fiji (1925.336), a Fijian kula bird (18/ $\mathrm{Psi} / \mathrm{a} / 1)^{17}$ whose highly valued red feathers were used to adorn finely woven Samoan waist-mats prized by Tongan and Fijian chiefs (Clunie 1986, 150), and a hybrid style of masi known as gatu vakaviti which brings together the rubbed style of Tongan decoration with Fijian stenciled border designs (Z 30433).

Central and enduring aspects of Fijian sociality were highlighted in a section entitled 'Viti' (Fiji), including the importance of chiefs, the value of tabua, the production and exchange of objects, and the yaqona ceremony. Here the temporal sequence was dramatically intersected by an installation of a solevu, a ceremonial gathering at which large numbers of goods are 
presented by one 'side' to another and then re-distributed. The installation provided a strong visual connection between the past and the present, with customary goods, such as mats, masi, yagona bowls and tabua, dating from the nineteenth to the twenty-first centuries. ${ }^{18}$

Chiefs \& Governors employed curatorial techniques of juxtaposition as a means of telling more complicated and nuanced stories while avoiding being overtly didactic. The careful placement of objects, museum texts, quotes, display cases and interpretative themes operated on different levels, both spatially and temporally. The first half of the exhibition situated the material on display within the dynamic history of Western Polynesia and emphasized core aspects of Fijian culture. The objects in the second half of the exhibition were positioned within early colonial contexts, the relations between chiefs and governors, Government House and the movement of the collections from Fiji to Cambridge. The two feature installations, the solevu in the first half of the exhibition and the re-presentation of the dining room wall at Government House (see below), although not simultaneously visible, showed contrasting ways that Fijian objects have been assembled, presented and re-distributed.

The juxtaposition of two or more perspectives, at times conflicting or incommensurable, aimed to highlight the complexity of colonial and personal relations. Gordon is credited with ushering in a more progressive form of British colonial rule that incorporated modified forms of native self-administration and aimed to protect indigenous rights over land. Yet he also opposed (at times violently) those who resisted colonial rule and aligned himself with the interests of the powerful chiefdoms of the coastal regions and small islands of eastern Fiji. Gordon's approach was epitomized by two key political events in 1876, which were contrasted in the central section of the exhibition. Gordon's 'Little War' in the Highlands of Viti Levu, between January and August, was precipitated by increased tensions among fiercely independent tribes who had never acknowledged the authority of the Cakobau government and were extremely suspicious of a new regime that aligned itself with a former enemy and victor of particularly vicious tribal wars (Sahlins 2004). Ultimately, the success of Gordon's small detachment demonstrated the might of the colonial government and asserted its claim to all of Fiji. The first Bose Vakaturaga, Great Council of Chiefs meeting, held at Waikava on the coast of Vanua Levu between November and December primarily involved the dominant chiefdoms of the coastal areas of eastern Fiji. Opened by Gordon and lasting nearly three weeks, the meeting provided the opportunity for lengthy discussions regarding the proposed structure and procedures of Fijian administration, many elements of which were simplified and codified according to Bauan practice. Various agreements were outlined in a letter to Queen Victoria, signed by the principal chiefs, and the meeting concluded with large feast and solevu, at which Gordon and other participants were presented with numerous gifts.

The positioning of historic photographs, such as those showing the inspection of the Armed Native Constabulary and the magiti feast following the Great Council of Chiefs meeting (Clunie and Herle 2004: 103-104), provided visual context for people, places and events while opening up further insights into multi-layered colonial and indigenous power relations (Fig. 3). A.J. Gordon's drawing of the fortified villages of Nasaucoko and Nakorovou as well as a 'cannibal' fork and a venerable yaqona bowl seized by government forces in the highlands were displayed alongside a small section of an enormous masi train (Z 30618), ${ }^{19}$ presented to Gordon at Waikava by the Tui Cakau (the ruler of Cakaudrove chiefdom and the most powerful chief in northern Fiji). The case opposite displayed various political gifts presented to Gordon and his wife, including the famous breastplate owned by Cakobau's father Tanoa, the fishhook gifted by Ma'afu, and tabua given to Gordon towards the end of the 'Little War', inscribed with the names of loyal villages and the dates of their presentation (MAA Z 3017).

Chiefs \& Governors aimed to develop an analytic symmetry between powerful Fijian chiefs and British colonial officials and explore the Fijianization of Government House in order to demonstrate multiple agencies within a network of colonial relations composed of people and things. Where possible particular objects were directly associated with specific people, places and events. Research on the context of the Government House collections was greatly enhanced by the extensive primary sources associated with its residents and numerous quotes were included throughout the exhibition to enrich the visitor's perspective on the objects displayed. Yet our presentation was limited by available sources and, it must be acknowledged that existing historical accounts focus on a small numbers of chiefly elite and 
originate from primarily British sources. The descriptions of the activities of key players such as Cakobau and Ma'afu, and the quotes attributed to them, were all mediated by European agents and are themselves a product of colonial hierarchies.

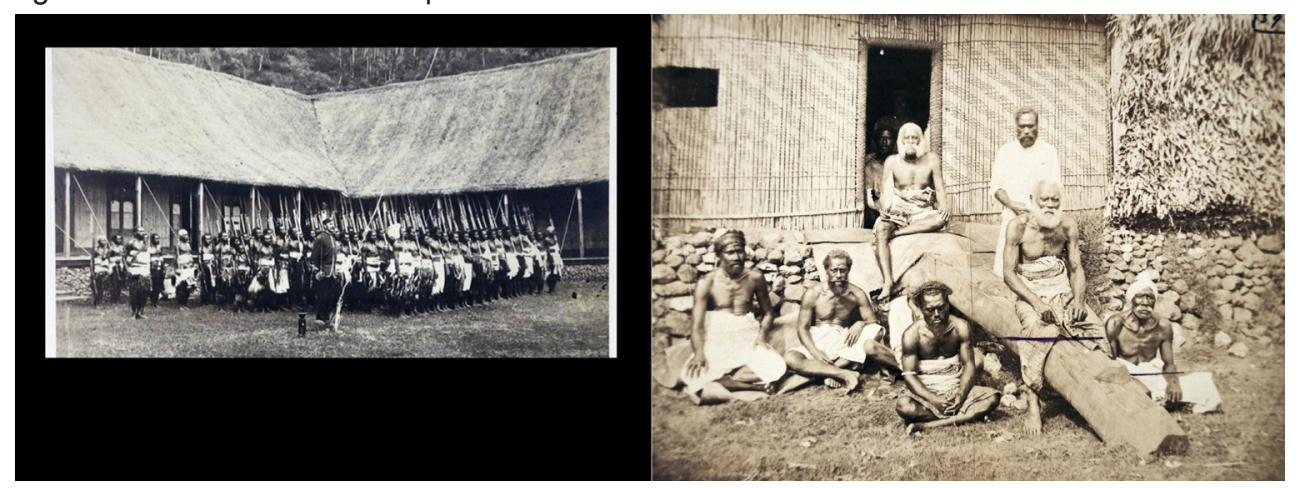

Figure 3. (Left) Swearing in of the governor, Sir Arthur Gordon at Government House. The Fijian Armed Native Constabulary, wearing traditional war dress and armed with Enfield rifles with bayonets, stand at attention under the command of Lieutenant Henry Olive. Photographed by F.H. Dufty, Nasova, Ovalau Island Fiji,1 September 1875, P.99734.VH. (Right) Chiefs at the meeting of the Council of Chiefs, Bosevakaturaga. Cakobau sits on a mat at the top of the log ramp leading to the chief's house, in front of his attendant who is holding a fan. His brother Ratu Josefa Celua is sitting further down the ramp. The chief sitting to his left is likely Ro Veceli Musudroka, the old Vunivalu of Rewa. Photo probably by F.H. Dufty, Waikava, Vanualevu, Fiji, November 1876. P.99842.VH

Acuratorial decision to evoke the1870s dining room through an installation aimed to re-activate the ambiguities of the Government House settling and harness the open-ended potential of contemporary museum display (Fig. 4). While it was impossible to identify and match the specific objects shown in the photograph, a similar arrangement of clubs and paddles was positioned on a printed cloth backdrop, fabricated to imitate the large gatuvakaviti barkcloth. A large pottery vessel and two miniature spirit houses were placed on a newly commissioned mat. ${ }^{20}$ The photograph of the dining room wall, alongside other images of Government House and quotes from its residents, ran along the length of the plinth underneath the display.

We usually have two chiefs at a time, with two interpreters and Mr Olive. To the first dinner we had the ex-King Thakombau [Cakobau] and another Chief ... [The Vunivalu is] a fine dignified old man, with a most commanding manner, and perfectly at his ease... Yesterday Maafu, the great Tongan Chief came; he is an extremely clever man, and the handsomest of them all (Lady Gordon's letter to her sister, October 1875 in Gordon 1897: 272).

A nearby display focused on the intimacy of the social relations that developed, particularly with members of Cakobau's family. Gifts presented to Gordon's children and their accompanying narratives were shown alongside bilo (coconut yaqona cups), as well as a selection of von Hügel's own photographs of his Fijian and settler friends and acquaintances. This evocation of the personal and familial, contrasted with (and complicated) the political formality of colonial relations represented in the previous section. The inclusion of personal quotes, largely drawn from Lady Gordon's letters and von Hügel's diary, provided rich and candid vignettes of people and events. They also provided a sense of intimacy with the protagonists, with the attendant risk of appearing as hagiography.

The Government House setting was equivocal. The friendly relations were part of a measured diplomacy between powerful Fijian and British political elites. Dominated by the theatrical re-presentation of a nineteenth century colonial display, the Government House section enhanced the experiential aspects of Chiefs \& Governors and highlighted political and cultural ambiguities. Drawing on Fijian notions of chiefly presentation, the weapons that decorated the 
dining room walls were a striking visual demonstration of Gordon's power and mana. The size of the dining room installation and its un-cased presentation visually positioned the objects at the centre of colonial power and materialized the close interactions and underlying tensions between the residents of Government House and high-ranking Fijians.

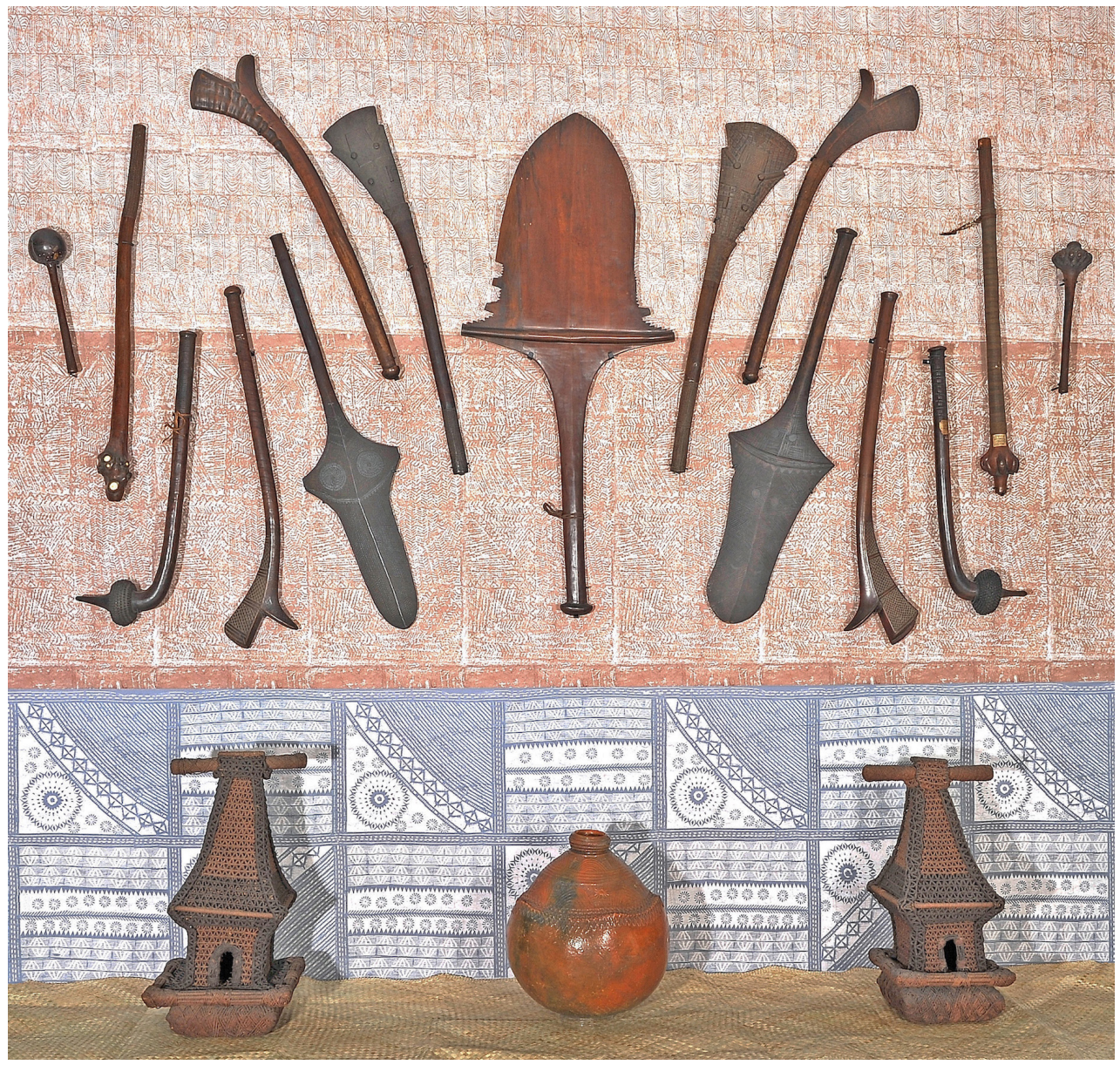

Figure 4. Installation evoking the dining room at Government House in Chiefs \& Governors, Photo: Gordon Brown, MAA, 2013.

\section{The Ongoing value of the Collections}

The concluding section of Chiefs \& Governors provided an overview of the transfer of the Government House collections to Cambridge, the foundation of the museum and the ongoing development of MAA's Fijian collections. Outlining some of the research conducted by members of the Fijian Art research project, it also explicitly addressed the pressing question of what we (as curators and researchers) do with large museum collections, and where the value of these historic objects lies today and in the future. In addition to demonstrating the skill and creativity of the makers, detailed collections-based research has led to many discoveries, illuminating our understanding of pre-colonial history, indigenous Fijian beliefs and practices, and the specificities of encounter and colonial relations. 
The collections have also reconnected museum staff and researchers with contemporary Fijian communities, both in Fiji and the UK. The Fiji Museum was a key project partner, facilitating collaborative and comparative work on the respective collections. Reciprocal relations were also developed with the Fiji High Commission in London, which provided links to members of the UK's Fijian community. Colonial history and contemporary international relations within the Commonwealth are reflected by the presence of over 10,000 Fijians living in the UK, many of whom are attached to the British army. Prior to installing the exhibition, Mrs Sera Tavainavesi, based at Tidworth Camp, and her colleagues including Manueli Tulo, Malakai Qoro, and Solo Baleisolomone from Carver Barracks, decorated the pillars in the gallery with masi bound with magimagi (coir cord). The elaborate magimagi weavings, known as lalawa, helped to transform the gallery into a Fjiian space, and opened up new relationships for the museum.

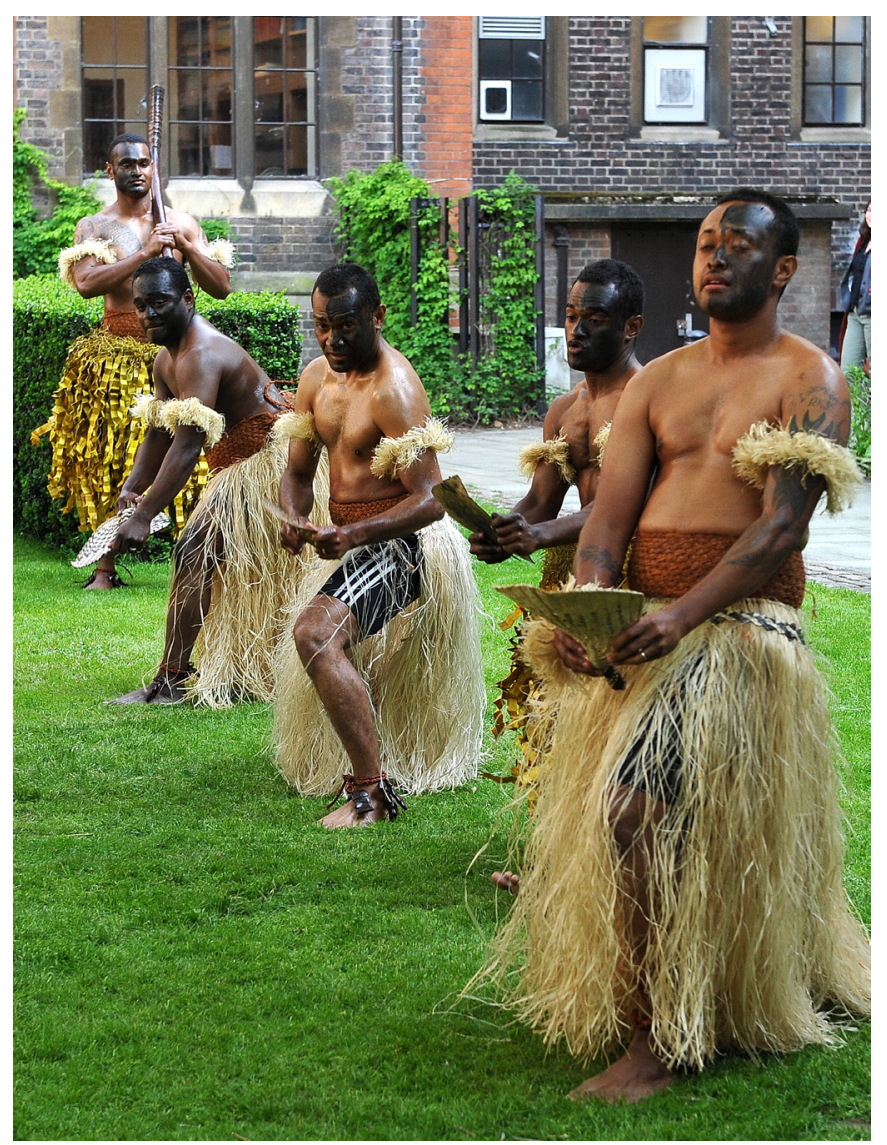

Figure 5. Fijian dancers at the opening of Chiefs \& Governors including Manueli Tulo and Malakai Qoro. The dancer at the back holds a club collected by von Hügel. Photo by Gordon Brown, MAA, 6 June 2013.
The Fijian High Commissioner, Solo Mara, opened the exhibition on 6 June 2013. Among the many guests, the Museum was honoured to host Sagale Buadromo, Director of the Fiji Museum, and Tarisi Vunidilo, the Fijian representative of the Pacific Islands MuseumAssociation (PIMA). News of the exhibition's preparations and opening was announced through the High Commission's networks and reported on the Project's Facebook page, which included many Fijian-based followers. Project staff were surprised and delighted by the enthusiastic response of the UK-based Fijian community - with customary songs and meke (dances) performed in the grassy courtyard to mark the occasion, and generous contributions of food and yaqona for the communal feast that took place afterwards. Project staff followed certain formal Fijian protocols, such as the ceremonial presentation of yaqona and a salusalu (neck garland) to the Fiji High Commissioner prior to the opening. MAA also needed to be flexible and quick to respond appropriately to unexpected situations; at the request of some of the male dancers, keen to perform a club meke but lacking the necessary accouterments, staff were happy to provide them with a couple of clubs from von Hügel's collection for the event (Fig. 5). The great enthusiasm and care prompted by the incorporation of treasured historic objects into a contemporary customary performance validated the position of modern Fijian dancers as valued stakeholders in MAA's collection, and demonstrated the benefit of museums adopting a less proprietorial (if conservation-cautious) attitude towards the material in their care (Herle 2008). 


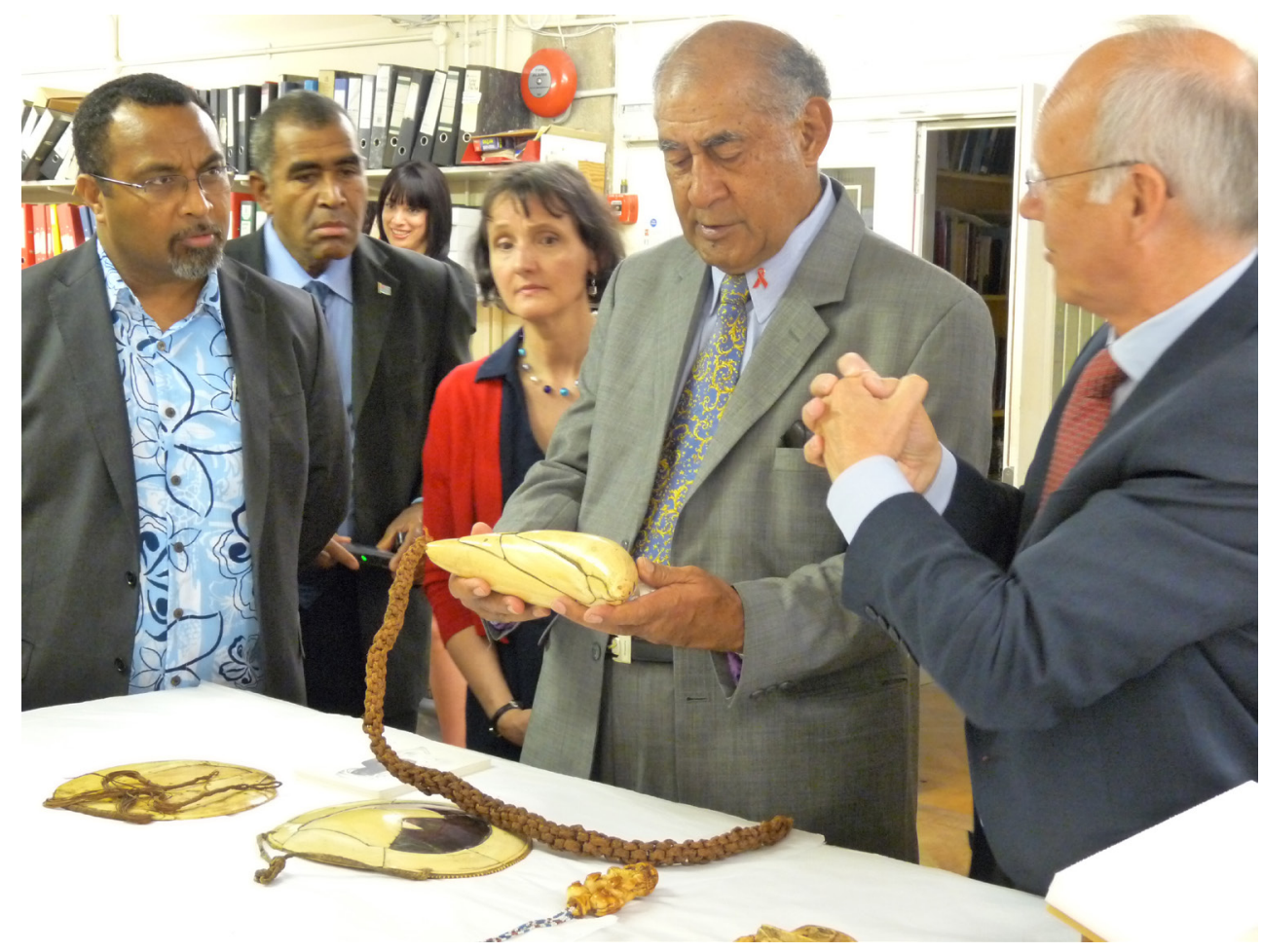

Figure 6. HE President Ratu Epeli Nailatikau, holding a 'super tabua' (1936.380), composed of several whales'teeth, presented by Cakobau's son Epeli Nailatikau (the President's namesake) to John Bates Thurston, Governor of Fiji from 1888-1897. In the background (I-r) are HE Solo Mara (Fiji High Commissioner to the UK), Mr Silivenusi Namata (Personal Staff Officer to the President) Katrina Igglesdon, Anita Herle, Steve Hooper. 28 July 2012, MAA.

The objects that marked alliances between chiefs and governors continue to act as diplomats between leading Fijian politicians and MAA, and more generally as ambassadors for indigenous Fijian culture to the museum's diverse audiences. For many Fijians the mana of MAA is demonstrated by its extraordinary Fijian collections. The Fijian Prime Minister HE Commodore Frank Bainimarama twice visited the Museum during the preparations for the exhibition, and MAAalso hosted President HE Ratu Epeli Nailatikau, who (as a descendant of Cakobau) retains a strong interest in early colonial history and the objects associated with his family. Objects from MAA's collections were lovingly handled and examined in the Museum's backrooms, and Fijian dignitaries were keen to have their photographs taken holding some of the most outstanding objects, such as the 'super tabua' (MAA1936.380), presented by Cakobau's son Epeli Nailatikau (the President's namesake) to John Bates Thurston, Gordon's secretary and later himself Governor of Fiji from 1888 - 1897 (Fig. 6). The potency of museum objects to connect distant people and places also opened up opportunities in Fiji. During research in Fiji in the run up to the exhibition, members of the Fijian Art Project were privileged to meet the President at Government House in Suva and were ceremonially hosted on Bau island. Project members needed to tread cautiously as they were projected into unfamiliar and highpowered political arenas.

A challenge for museums such as MAA, with large international collections, is to develop and sustain productive relationships with source communities, while catering to diverse audiences. Outside of formal networks, the main contact with Fijians (and others) was through the project's Facebook page. In the UK, Fijians who had heard about the Cambridge exhibition visited MAA with friends and colleagues. While we met face-to-face with some visitors, often 
museum staff only found out about these visits afterwards, through the comments recorded in the visitors' book. The goal of reaching out to UK-based Fijians was limited by a lack of resources as well as the dispersal and movement of army personnel. During the course of the exhibition, numerous gallery talks, workshop and events were developed for various audiences, with the multivocality of objects and contexts providing a rich resource for developing different pathways through the exhibition. A teaching collection assembled by co-curator Lucie Carreau extended the Museum's core outreach activities and was used for a range of specialist and family friendly activities. One of the most successful events, which brought together UK-based Fijians and broader public audiences was a Vosa Vakaviti workshop initiated and led by Ana Lavekau, a Fijian fashion designer and Corporal based at Swinton Barracks in Hampshire. Using Chiefs \& Governors as a backdrop for cultural re-vitalization activities, the workshop included language training, pottery making and dance. It culminated in a public meke in the museum's courtyard, which delighted museum visitors and staff as well as the young performers and their families.

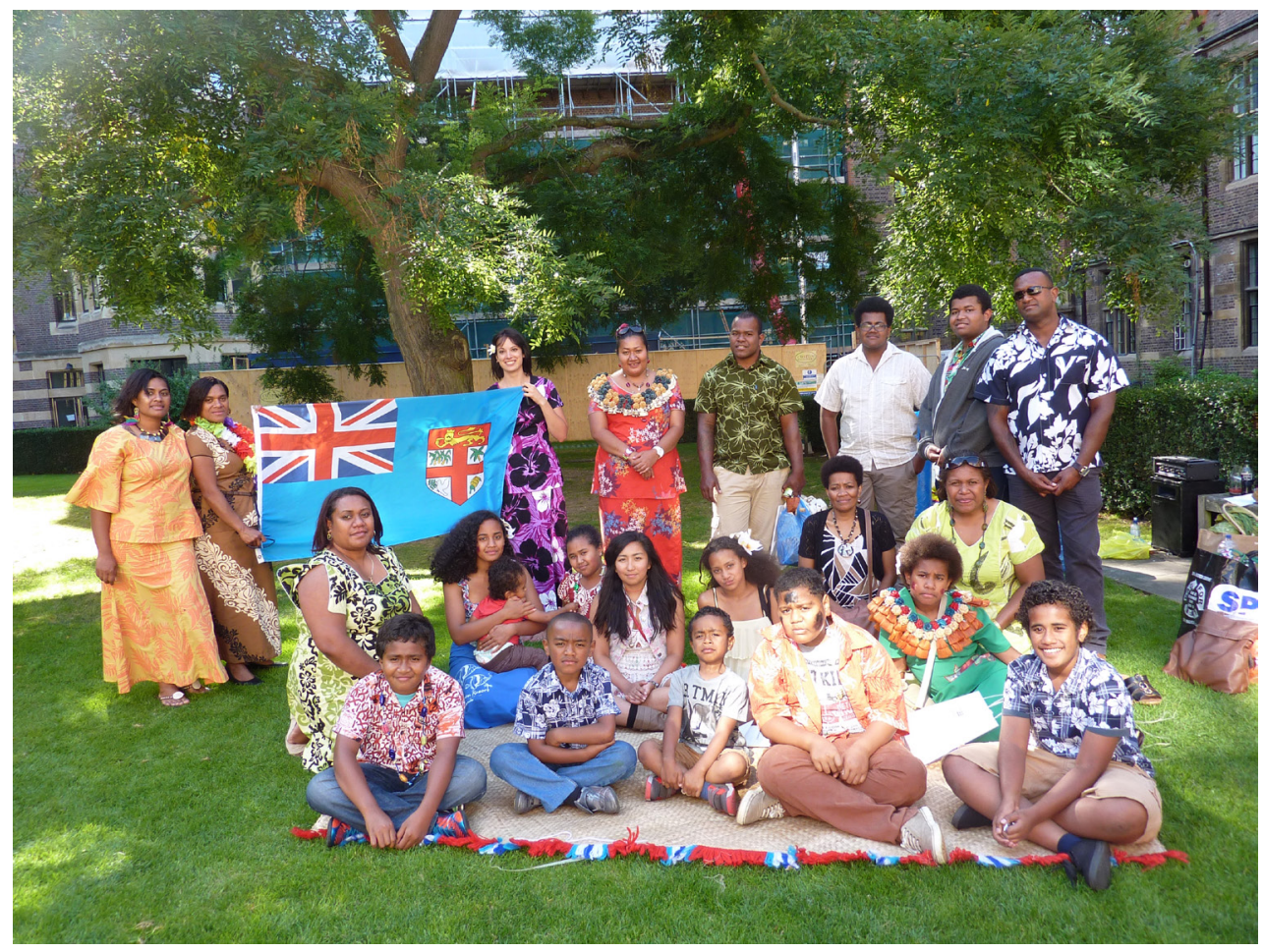

Figure 7. Participants of the Vosa Vakaviti workshop led by Ana Lavekau (left) for UK-based Fijian youth in the courtyard of MAA, Vosa VakaViti is a language and coulture programme for diasporic communities and is established throughout the UK as well as New Zealand and Australia. Photo by Anita Herle 30 August 2013.

Chiefs \& Governors drew on the strengths of MAA's outstanding founding collections to explore the specificity and nuances of early colonial relations in Fiji and highlight the multiple agencies that brought these extraordinary things to Cambridge. The open-ended presentation and the multivocal potential of objects enabled the telling of numerous inter-related stories about the past, present and future. Outside the Government House frame, the objects speak to the skill and imagination of their makers, of ongoing exchange relations and the enduring power of chiefs. Drawing on the comments in the visitor's book, ${ }^{21}$ backed up by formal reviews and gallery discussions, there were numerous references to 'history in all its detail' and the continuing relations between Britain and Fiji. Non-Fijian visitors recounted travel experiences in Fiji or expressed their interested in visiting. 'Amazing! Fiji is my next holiday destination. Thanks.' Fijian visitors were surprised and thrilled by some of the rarer items on display 'Tanoa's breastplate 
in particular was a joy to behold - Loloma!' Many of the objects displayed - such as tabua, masi and yaqona bowls - remain ubiquitous in Fiji today. The presence of the collections in Cambridge did not give rise to concerns over appropriation, but rather prompted a strong sense of cultural belonging, especially for members of diasporic communities. 'Proud Fijian in Cambridge today... Happy to see everyone interested in our artifacts.' 'Great to bring my kids here to see their culture and history and learn where they are from 'Kai Viti (I'm Fijian) Sa Maleka (lovely)!!! Vinaka vaka levu (thank you)'.

Visitor feedback and audience evaluation techniques provide useful, if limited, insights into the impact of exhibitions. The creation of Chiefs \& Governors and the politics of its reception were a crucial part of the research process into the specificity and nuances of encounter and early colonial relations in Fiji, not simply a presentation of research done elsewhere (Herle 2013). Chiefs \& Governors and the work of members of the Fiji Art Project has prompted further visits by Fijians to MAA, and led to new projects and collaborations, most notably the production of the largest and most comprehensive exhibition about Fiji ever assembled, Fiji: Art \& Life in the Pacific (15 October 2016 -12 February 2017) at the Sainsbury Centre for Visual Arts (SCVA) (Hooper 2016), to which MAA lent over 100 objects.

Attention to the colonial entanglement of historic collections also provides insights into the diffuse legacies today. The commission of a small 8 metre drua (double-hulled sailing canoe) for Fiji: Art \& Life in the Pacific is an apt example of the potency of exhibitions and the ability of objects to invigorate social relations and accumulate new meanings. The production of the drua, the Adi Yeta, ${ }^{22}$ in Fiji, encouraged the retention of traditional boat-building skills and was proudly sailed in Suva harbour before being shipped to the UK (Hooper 2016: 242). Prior to opening of the exhibition, Adi Yeta was included in Queen Elizabeth's ninetieth birthday pageant at Windsor Castle in May 2016, to the delight of its makers, the Fiji government and Fijians worldwide, reinforcing the special relationship between Fiji and the British Crown. In November 2017 Adi Yeta will be in Bonn, where it will be part of cultural programme for the UN Climate Change Conference, presided over by the Government of Fiji with German support. In 2018 the drua will go to the National Maritime Museum in Greenwich, as part of their new Pacific Gallery.

Research on the originating context of MAA's founding Fijian collections, has revealed multiple agencies within colonial relations and highlighted the potency of objects in crosscultural encounters and the fluid transactional nature of object histories. An exploratory and collaborative approach has demonstrated the potential of collections to connect museums to communities of origin and link historic objects with contemporary concerns. The process of creating Chiefs \& Governors, which involved a close attention to the materiality of the objects and the skill of their production as well as the techniques and effects of museum display, provided insights into the specificity of colonial relations in Fiji in the mid 1870s and made the nuances of those relations visible. The open-ended approach of the exhibition also encouraged visitors to make their own connections between the objects, people and stories on display. The continued circulation and re-display of the collections has prompted new meanings and led to the production of new objects, now situated within networks of post-colonial relations in local and international arenas. Contemporary responses to historic objects and the creation and mobilization of the Adi Yeta demonstrates how the political is continually reconstituted by shifting assemblages of people and things (Latour and Weibel 2005).

Received: 30 September 2017

Finally Accepted: 10 July 2018

\section{Acknowledgements:}

This article draws on research supported by Arts and Humanities Research Council as part of the Fijian Arts Project (2011-2014) led by Steven Hooper at the University of East Anglia in collaboration with the Museum of Archaeology and Anthropology at the University of Cambridge. I am grateful to the Project team for their support and particularly thank Karen Jacobs and Andrew Mills for their detailed comments on an early version of this paper and Stephen Hooper and Katrina Igglesden for clarifying details regarding Adi Yeta and COP23. I also thank Elizabeth Edwards, Haidy Geismar, two anonymous reviewers and the editors. Chiefs \& Governors: Art and Power in Fiji was co-curated with Lucie Carreau. 


\section{Notes}

1 Chiefs \& Governors was curated by Anita Herle and Lucie Carreau with the input from of the members of the Fijian Art Research Project.

2 The Fijian Art Research Project (2011-2014) was led by Steven Hooper, Director of the Sainsbury Research Unit for the Arts of Africa, Oceania and the Americas at the University of EastAnglia, in collaboration with staff at the University of Cambridge Museum of Archaeology and Anthropology. The core members of the research team also included Lucie Carreau, Fergus Clunie, Katrina Igglesden, Karen Jacobs and Andrew Mills.

3 These specimens, along with plant samples collected by Anatole von Hügel, are now in the Natural History Museum, which separated from the British Museum in 1881.

4 Von Hügel donated numerous bird skins to the University of Cambridge Museum of Zoology.

5 See Lord Stanmore (Gordon) in the list of Al members and their dates of joining, Journal of the Anthropological Institute Vol 30, 1900, 1-12.

6 British Museum Anthropology Centre Fiji/Tonga box file Oc/B84/1.

7 Following Cakobau's conversion to Christianity in 1854, largely for political reasons, the number of Fijian Methodists rose sharply from approximately 5,000 to nearly 125,000 by the time of Cession (Thornley: 2002, 80).

8 Many of these watercolours are included alongside photographs in Gordon Cumming's two large albums, now in MAA's collections (A.169.GCUM, A.170.GCUM).

9 Tanoa was shown wearing this breastplate in 1840 in a drawing by Alfred Agate, artist on the United States Exploring Expedition (Clunie 1983),

10 For an analogous Tongan example see Mills 2009.

11 See for example Gordon's letter to Lord Selborne on 7 September 1880 (Gordon 1912: 431)

12 For example, in 1885 von Hügel sent Fijian 'duplicates' to the British Museum and the Australian Museum in Sydney,

13 The most significant addition to the Fijian collections was over 300 objects donated over several decades from 1932 by George Kingsley Roth, a colonial administrator in Fiji between the late 1920s and 1950s (Herle and Carreau 2013: 121-123).

14 See for example the results of a research project led by Elizabeth Edwards 'Photographs, Colonial Legacy and Museums in Contemporary European Culture' (2010-2012), funded by the Humanities in the European Research Area (HERA) and involving the UK, the Netherlands and Norway. http://photoclec.dmu.ac.uk accessed 1 Sept 2017).

15 In 2016, 27 years after 'Into the Heart of Africa', Mark Engstron, the Deputy Director of the Royal Ontario Museum issued a formal apology for the exhibition, noting that it had inadvertently perpetuated an atmosphere of racism (National Post Newpaper, 10 November 2016 http://nationalpost.com/news/toronto/royal-ontario-museum-apologizes-for-racistafrica-exhibit-it-held-nearly-30-years-ago accessed 1 September 2017.

16 Katrina Igglesden, a doctoral student and member of the Fijian Art research project, made a contemporary Fijian collection for MAA in 2012-2013, including items commissioned especially for the exhibition with the support of Crowther Beynon Fund, University of Cambridge. 
17 One of two birds collected by von Hügel on loan from the University of Cambridge Zoology Museum.

18 Gordon also donated a large section of this masi, (Z 3862), over 14 meters in length, which was unrolled at a public 'Fiji day' in conjunction with the exhibition.

19 The mat was commissioned by MAA via Katrina Igglesden and made by Mrs Milly Rayawa in Suva in 2013.

20 Approximately 650 people signed the visitors' book, with less than half making specific comments about the exhibition. Well over 50,000 people visited Chiefs \& Governors.

21 The Adi Yeta was named in appreciation of Henriette 'Jette' Pleiger of the Bundeskunsthalle in Bonn Germany, who was played an important role in securing institutional support for the commissioning the drua.

\section{References}

Bennett, T, Dibley, B. and Harrison, R. (2014) 'Introduction: Anthropology, Collecting and Colonial Governmentalities', History and Anthropology, 25 (2) 137-149.

Cameron, F. and McCarthy, C. (2015) 'Introduction: Museum, Field, Colony, displaying and governing people and things', museum and society, 13 (1) 1-6.

Carreau, L. (2013) 'Ivory Breastplate Civatabua', in Anita Herle and Lucie Carreau, (eds) Chiefs \& Governors: Art and Power in Fiji, 91-92, Cambridge: Museum of Archaeology and Anthropology.

Clunie, F. (1983) 'Ratu Tanoa Visawaqa's Breastplate', Domodomo, 1 (3) 123-25.

Clunie, F. (1986) Yalo i Viti: A Fiji Museum Catalogue, Suva: Fiji Museum.

Clunie, F. (2013) 'Twinned Ivory Figure', in Anita Herle and Lucie Carreau, (eds) Chiefs \& Governors: Art and Power in Fiji, 55-56, Cambridge: Museum of Archaeology and Anthropology.

Clunie, F. and Herle, A. (2004) 'Fijian Collections Research at the Cambridge University Museum of Archaeology and Anthropology', Journal of Museum Ethnography, 16, 101-10.

Dudding, J. (2013) 'Identifying Dufty's Studio Photographs', in Anita Herle and Lucie Carreau (eds) Chiefs \& Governors: Art and Power in Fiji, 115-116, Cambridge: Museum of Archaeology and Anthropology.

Derrick, R. (2001) [1946] A History of Fiji, Revised Edition. Suva: Government Press.

Ebin, V. and Swallow, D. (1984) 'The proper study of mankind...' Great Anthropological Collections in Cambridge, Cambridge: Heffers.

Edwards, E. and Mead, M. (2013) 'Absent Histories and Absent Images: Photographs, Museums and the Colonial Past', museum and society 11 (1) 19-38.

Edwards, E. (2016) 'The colonial archival imaginaire at home', Social Anthropology/ Anthropoogie Sociale, 24 (1) 52-66.

Elliott, M. and Thomas, N. (eds) (2011) Gifts and Discoveries: The Museum of Archaeology and Anthropology, Cambridge, London: Scala Publishers Ltd. 
Gordon Cumming, C. (1883) At Home in Fiji, New York: A.C. Armstrong.

Gosden, C. and Larkin, F. (2007) Knowing Things: Exploring the Collections at the Pitt Rivers Museum 1884 -1945, Oxford: Oxford University Press.

Gordon, C. H. (Lord Stanmore) (1897) Fiji: Records of Private and of Public Life, Vol. I. Edinburgh: R. \& R. Clark, Ltd.

(1901) Fiji: Records of Private and of Public Life. Vol. II, Edinburgh: R. \& R. Clark, Ltd.

(1912) Fiji: Records of Private and of Public Life Vol. IV, Edinburgh: R. \& R. Clark, Ltd.

Hau'ofa, E. (1993) 'Our Sea of Islands', in E. Hau-ofa, V. Naidu and E. Waddell, (eds) New Oceania: rediscovering our Sea of Islands, 2-16. Suva: The University of the South Pacific.

Herle, A. (2008), 'Relational Objects: Connecting People and Things Through Pasifika Styles', International Journal of Cultural Property, 15, 159-179.

Herle, A. (2013) 'Exhibitions as Research: Displaying the Technologies that Make Bodies Visible' in S. Dudley and K. Message (eds.) Museum Worlds: Advances in Research, Berghahn, 1, $113-135$.

Herle, A. and Lucie C. (eds) (2013) Chiefs \& Governors: Art and Power in Fiji. Cambridge: Museum of Archaeology and Anthropology.

Hooper, S. (2006) Pacific Encounters: Art and Divinity in Polynesia 1760-1860, London: The British Museum Press.

Hooper, S. (2013), 'Tabua', in Anita Herle and Lucie Carreau (eds) Chiefs \& Governors: Art and Power in Fiji, 21-22, Cambridge: Museum of Archaeology and Anthropology.

Hooper, S. (2013) '“Supreme among our Valuables”: Whale Teeth, Tabua, Chiefship, Power and Value in Fiji,' Journal of the Polynesian Society, 122 (2) 102-160.

Hooper, S. (2016) Fiji: Art and Life in the Pacific, Norwich: Sainsbury Research Unit for the Arts of Africa, Oceania \& the Americas, UEA.

Jacobs, K. (2013) 'Liku skirts', in Anita Herle and Lucie Carreau (eds) Chiefs \& Governors: Art and Power in Fiji, 71-71, Cambridge: Museum of Archaeology and Anthropology.

Latour, B. and Weibel, P. (eds) (2005) Making Things Public: Atmospheres of Democracy. Karlsruhe: Zentrum für Kunst und Medientechnologie (ZKM).

Mills, A. (2013), 'Fijian Weapons', in Anita Herle and Lucie Carreau (eds) Chiefs \& Governors: Art and Power in Fiji, 53-54, Cambridge: Museum of Archaeology and Anthropology.

Mills, A. (2009) 'Akau Tau: Contextualising Tongan War-Clubs', Journal of the Polynesian Society, 118 (1) 7-46.

Modest, W. (2014), 'Museums and the Emotional Afterlife of Colonial Photography', in Edwards, E. and Lien, W (eds). Uncertain Images, Museums and the Work of Photographs, 21-42, London and New York: Routledge. 
Roth, J. and Hooper, S, (eds) (1990), The Fiji Journals of Anatole Von Hügel, 1875-1877, Suva: Fiji Museum in association with Cambridge University Museum of Archaeology and Anthropology.

Sahlins, M. (2004) Apologies to Thucydides: understanding history as culture and vice versa, Chicago: University of Chicago Press.

Thomas, N. (1989) 'Material Culture and Colonial Power: Ethnological Collecting and the Establishment of Colonial Rule in Fiji', Man, 24 (1) 41-46.

Thomas, N. (2011) 'Von Hügel's curiosity: Encounter and experiment in the new museum' HAU: Journal of Ethnographic Theory, 1 (1) 299-314.

Thornley, A. (2002) Exodus of the I Taukei: The Wesleyan Church in Fiji, 1848-1874, Suva: Institute of Pacific Studies, University of the South Pacific.

\section{*Anita Herle}

Anita Herle (BA, M.Phil, PhD, FRAI) is Senior Curator for World Anthropology, with particular responsibility for the Pacific and the Americas. She has regional interests in Torres Strait, Vanuatu, Fiji and Canada. Her research topics include museum anthropology, the early history of British anthropology, art and aesthetics, and visual histories. She coordinates the MPhil in Social Anthropology and Museums and teaches in museology, the anthropology of art and visual media.

Her research is concerned with a range of ethnographic and disciplinary contexts for MAA's collections and their many contemporary resonances. Within the history of British anthropology, she has explored the intersection between different knowledge systems, the complex relations that develop in the anthropological field and the potency of objects and photographs in relational encounters. Her research has resulted in the production of collaborative exhibitions at MAA and elsewhere. She was lead curator (with Mark Elliott and Rebecca Empson) for 'Assembling Bodies: Art, Science and Imagination', part of the Leverhulme funded project on Changing Beliefs of the Human Body (2005-2009) and is currently a co-investigator on the AHRC funded Fijian Art research project (2011-2014).

Senior Curator, Reader in Museum Anthropology

Museum of Archaeology \& Anthropology

Department of Social Anthropology,

University of Cambridge

ach13@cam.ac.uk 